\title{
Seed anatomical studies on dormancy and germination in Chamaecrista absus
}

\author{
H. M. Pallavi ${ }^{1 *}$, K. Vishwanath ${ }^{2}$, Bapurayagouda Patil ${ }^{1}$, N. Naveen ${ }^{1}$, and Manjunath Thattimani ${ }^{1}$ \\ ${ }^{1}$ Main Horticulture Research and Extension Centre, University of Horticultural Sciences, Bagalkot -587104, INDIA \\ ${ }^{2}$ Zonal Agriculture Research Station, V.C. Farm, University of Agricultural Sciences, Bangalore-571045, INDIA \\ "Corresponding author.E-mail: pallavihm@gmail.com
}

Received: July 17, 2015; Revised received: March 1, 2016; Accepted: May 25, 2016

\begin{abstract}
Present study was conducted to analyze the anatomical structure of seed to study the dormancy behaviour in Chamaecrista absus. Seed germination behaviour was also studied after breaking the seed dormancy by artificial seed treatments. The anotamical studies revealed that seed has apical hilar region and seed coat has four layers consisting of outer cuticle, sub cuticle, palisade layer and inner tegma leading to physical dormancy. Outer cuticle and sub cuticle layers are very hard to break naturally and hence seeds possess hard seed coat dormancy. This physically hard seed coat should be made soft to enhance germination. Studies to break dormancy were conducted involving treatments like hot water, hormones and in combinations of both. The results revealed that seeds dipped in boiling water made inner layers permeable for water absorption in hilar region and thus germination enhanced. In specific seeds treated with boiling water for 5 minutes recorded higher germination (82\%) over untreated control (26\%). . Other artificial treatments with hormones gibberellic acid (33\%) and ethrel (34 \%) did not enhanced the germination significantly over control. C. absus has hard coat dormancy and can be overcame by treating seeds with boiling water treatment.
\end{abstract}

Keywords: Germination enhancement, Hard seed coat, Hot water treatment, Physical dormancy, Plant hormone

\section{INTRODUCTION}

Existence and survivality of any plant species depends on its ability to germinate and establish as an individual plant. If seeds germinates at wrong time and at wrong place will lead to death of the plant and is eliminated by nature. To assure their survival, species in particular wild plants have mechanisms to delay germination by going to quiescent stage. This mechanism of viable seed unable to germinate immediately after repining stage is called as dormancy. Each plant species have particular requirements and conditions for germination, growth and reproduction which are all well balanced by nature (Li et al., 1999).

Plant species shows dormancy depending upon the environmental conditions in which the seed is able to germinate. Dormant seeds does not germinate even under favourable conditions until it undergo series of changes favouring germination process (Ameer et al., 2013). Recent definition of seed dormancy says that this character is an innate seed property determined by genetics that defines the environmental conditions in which seed is able to germinate (Finch-Savage and Leubner-Metzger, 2006).

Seed dormancy is removed naturally by series of mechanisms like drying, heating, wetting, microbial interaction, complete development of immature embryo and is many other reasons which can overcome hurdles of germination. Moisture and Oxygen are the most important factors required for germination. Seeds remain viable but ungerminated by avoiding moisture and oxygen to enter their system. One such mechanism which preents entry of to prevent moisture and oxygen into the embryo is the impermeable seed coat, acting as a physical barrier between embryo and atmosphere and classified as physical seed dormancy. This kind of physical dormancy is reported in 17 families of angiosperms including Fabaceae and its subfamilies Faboideae and Caesalpinoideae (Baskin and Baskin, 2001). It was also reported that chemical substances like polysaccharides, waxes, fats and resinous are present in seed coat of Fabaceae which are impermeable to water (Bewley and Black, 1994). Similarly in subfamily Caesalpiniodeae, callose are found on the upper portion of macrosclereid cells in seed coat (Ma et al., 2004) which restricts the entry of water into the seeds.

Chamaecrista absus belongs to the family Fabaceae and subfamily Caesalpinoideae. This is a wild herb grown widely in tropical climate, has number of medicinal properties and commonly known as chaksu. Leaves are used as purgative and remedy for coughs, asthma and bronchitis. Seeds are bitter, astringent, stimulant and diuretic. This medicinal property has made the plant to put under cultivation where, presence of dormancy has made difficult for propagation. C. abus seeds are $4.5 \mathrm{~mm} \times 4.00 \mathrm{~mm}$ trapezoid ovoid, shiny and black in colour, which are very hard to 
break. In nature, this plant germinates after shower during August and produces seeds by November or December. Seeds produced were buried inside the soil and show dormancy till it experience dry heat during summer (March-May) and wetting during Rainy season (June- July). This drying and wetting action makes the seed to overcome dormancy and germinates after showers (August). This cycle is maintained by $C$ absus for its existence in nature. Presence of dormancy in $C$. absus has also been reported by Gaddanakeri et al. (2009). However, the type of dormancy and behaviour is not studied and reported, while, in other species studies have been conducted to overcome dormancy by artificial seed treatments (Negi and Sharma, 2012; Amira and Mohamed, 2013). Souza et al. (2012) found that an alternative temperature also helped to remove the dormancy in Schizolobium parahyba (Caesalpinoideae). The purpose of this study was to study the dormancy behaviour by analyzing the anatomical structure and changes in seed coat leading to germination in C. abus.

\section{MATERIALS AND METHODS}

Seed source: Fresh and mature seeds were collected from North West region of India (Lat: $16^{0} 20^{\prime} 50^{\prime} \mathrm{N}$; Lon: $075^{0} 37^{\prime} 05^{\prime}$ E) during November, 2013. Seeds were cleaned and dried to $9 \%$ moisture and were used for the study. Average weight of C. abus seed is 23$25 \mathrm{mg}$.

Structural analysis of the seed: Seed coat morphological analysis was conducted by observing seed and seed coat using stereo zoom microscope (Motic, 40x zoom). Seed coat sections were prepared with water and were observed for morphological structures under stereo zoom microscope and pictures were capture using attached digital camera. .

Seed treatment and seed germination: A series of pilot experiments (data not given ) to determine the effective hot water temperature (from $60^{\circ} \mathrm{C}$ to $100^{\circ} \mathrm{C}$ ) and duration of treatment ( 2 mins to $10 \mathrm{mins}$ ) and concentration of hormones from $100 \mathrm{ppm}$ to $1000 \mathrm{ppm}$, on germination and seedling vigour were conducted. Based on the results of pilot study the following levels of treatments were selected for further experiment.

$\begin{array}{ll}\text { T1: Hot water }\left(80^{\circ} \mathrm{C}\right) 15 \text { mins } & \text { T9: T2 + T6 } \\ \text { T2: Hot water }\left(80^{\circ} \mathrm{C}\right) 20 \text { mins } & \text { T10:T3+ T6 } \\ \text { T3: Boiling water } 3 \text { mins } & \text { T11: T4+T6 } \\ \text { T4: Boiling water } 5 \text { mins } & \text { T12: T1+T7 } \\ \text { T5: Boiling water } 10 \text { mins } & \text { T13: T2+ T7 } \\ \text { T6: GA3 500 ppm } & \text { T14: T3+T7 } \\ \text { T7: Ethrel } 150 \mathrm{ppm} & \text { T15: T4+T7 } \\ \text { T8: T1 + T6 } & \text { T16: Control }\end{array}$

Fresh seeds were exposed to the following artificial treatments in 4 replications (50 seeds/ replication):

Hot water: Seeds were dropped in hot water having $80{ }^{\circ} \mathrm{C}$ temperature for 15 and 20 minutes. Later seeds were removed from hot water and shade dried for 6 hours and tested for germination.
Boiling water: Seeds were dropped in boiling water for 3 and 5 minutes and later seeds were removed and shade dried for 6 hours and tested for germination.

Hormone treatment: Seeds were soaked in GA3 (500 ppm) and Ethrel (150 ppm) for 24 hours followed by shade drying for 6 hours and tested for germination. Seed germination: Treated seeds were placed in between two wetted germination paper and rolled before keeping in plant growth chamber maintained at $30^{\circ} \mathrm{C}$ and $90 \%$ Relative humidity for 14 days. Seedlings with fully grown root and shoot were counted as normal seedlings, un-imbibed seeds as hard seeds, absence of root or shoot as abnormal, imbibed but not germinated as fresh ungerminated seeds (FUG) and decayed seeds as dead seeds. Germination of seeds were counted on $8^{\text {th }}$ day of the test and recorded as first count and final germination was counted on $14^{\text {th }}$ day of the test.

The data pertaining to the observations recorded in the laboratory were analyzed using Completely Randomized Design adopting the procedure as described by Panse and Sukhatme (1967). The critical difference (CD) was computed at $1 \%$ probability.

\section{RESULTS}

Structural analysis of seed: Hilar region in C. absus is apical and consists of micropyle, hilum and lens (Fig. 1A). The testa consists of four layers, outer cuticle layer, sub-cuticle, palisade layer and inner white layer (Tegma). Outer cuticle layer is black, thin and tough. Palisade layer has macroscleroids cells which are linear and compactly arranged to act as barrier for water entry. Whereas, in the hilar region the thickness of middle palisade layer is thicker and supported by sub-cuticular on upper side and osteosclereids in the lower side (Figs. 2A and B).

Seed treatment resulted in a series of morphological changes on outer seed coat of the seed (Fig. 3). Initially oozing of slimy mucilaginous material was observed on few spots of seed coat. Later these secretions spread and covered whole seed coat and looked like a mass of cotton. The erosion was slimy to touch and found only on outer seed coat. When this slimy material was removed on the seed coat, the outer cuticle layer was eroded and these were in spots arranged in a line on the seed coat (Fig. 3 E). Seed treatment resulted in removal of outer hard cuticular layer and sub cuticular layer also. Further, Palisade layer became soft and inner thin white cell layer turned into a thick leathery layer after imbibition. Finally, size of the seed increased by one and half times then the hard seeds after intake of water (Fig. 4).

The thick hard seed coat became soft and leathery after breaking dormancy by seed treatment. The seed coat thickness got reduced greatly near the hilar region and resulted in entry of water leading to imbibition process. The initiation of germination process resulted in rupturing of carpellary mircopyle region through 
which radical breaks the seed coat and emerges as new seedling. The thickness of seed macrosclereids near carpellary micropyle is less resulting in slit like feature, when compared to other parts of hilar region.

Effect of artificial seed treatment on break seed dormancy: Seed dormancy in C. absus was found to overcome after seed treatment. Seed morphology was found to be different in dormant and non-dormant seed during germination process. Among different treatments, hot water treatment resulted in breaking of hard seed coat and helped in imbibition process. In particular seeds treated in boiling water showed maximum per cent of imbibed seeds than untreated control. The results obtained after artificial seed treatment on germination is depicted in table 1 . There was significant effect among the treatments used to overcome dormancy.

As the temperature of water increased there was a significant improvement in imbibition and germination. Morphological changes in the hilar region after hot water treatment was observed and found that lens area became wider and deeper to facilitate water absorption when compared to untreated dormant seed. Also we found erosion of cuticle layer and brachysclereids and exposing osteosclerides and macroscleroids. However, seeds remain hard until the inner layers absorb water and became soft. Water absorption in non-dormant seeds leads to increase in the cell size of macrosclerides and also thickened the inner tegma layer.

Seeds boiled in water for 5 minutes recorded higher percentage germination ( $82 \%$ ) and least hard seed per cent $(3 \%)$. A negative relation was established between germination and hard seed per cent in all artificial seed treatments. When the temperature and duration of the hot water treatment was increased to 10 mins (T5) there was enormous increase in dead seeds
(54\%) and drastic reduction in germination (20\%). Fresh dormant seeds before treatment showed only 26 per cent germination and higher number of hard seeds (69\%) even after 14 days of test. While, seeds treated with plant hormones like Gibberlic acid (33\%) and ethrel $(34 \%)$ does not showed significant improvement on germination over the untreated control and they were on par with each other.

Early germination was achieved when seeds were boiled in water for 5 mins (56\%) followed by 3 mins $(45 \%)$ on $8^{\text {th }}$ day of test. Maximum percentage of seeds died when boiled in water for 10 mins (54\%). Further, there was no significant improvement in germination when water boiled seeds treated with hor-

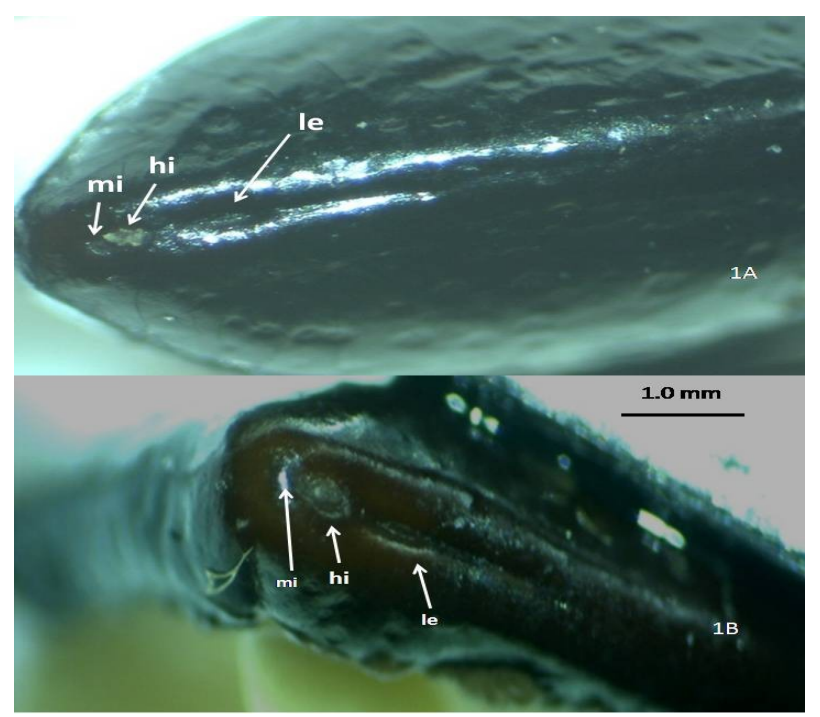

Fig. 1. Hilar region of the C. absus showing micropyle (mi); Hilum (hi) and Lens (le) region 1A: Dormant seeds; 1B: Non -dormant seed after treatment.

Table 1. Influence of different seed treatments on germination and hard seeds in C. absus. (Abnormal seedlings are not indi cated)

\begin{tabular}{|c|c|c|c|c|c|}
\hline Treatments & $\begin{array}{l}8^{\text {th }} \text { day of test } \\
\%\end{array}$ & $\begin{array}{l}\text { Germination } \\
\% \\
\end{array}$ & $\begin{array}{l}\text { Hard seeds } \\
\%\end{array}$ & $\begin{array}{l}\text { Fresh Ungerminaed } \\
\%\end{array}$ & $\begin{array}{l}\text { Dead seeds } \\
\% \\
\end{array}$ \\
\hline $\mathrm{T}_{1}$ : Hot water $\left(80^{\circ} \mathrm{C}\right) 15 \mathrm{mins}$ & 22 & 32 & 48 & 10 & 9 \\
\hline $\mathrm{T}_{2}:$ Hot water $\left(80^{\circ}\right) 20 \mathrm{mins}$ & 23 & 38 & 44 & 4 & 12 \\
\hline $\mathrm{T}_{3}$ : Boiling water $3 \mathrm{mins}$ & 45 & 61 & 16 & 8 & 8 \\
\hline $\mathrm{T}_{4}$ : Boiling water 5 mins & 56 & 82 & 4 & 1 & 10 \\
\hline $\mathrm{T}_{5}$ : Boiling $10 \mathrm{mins}$ & 18 & 20 & 2 & 2 & 54 \\
\hline $\mathrm{T}_{6}: \mathrm{GA} 3: 500 \mathrm{ppm}$ & 17 & 33 & 57 & 6 & 3 \\
\hline $\mathrm{T}_{7}$ : Ethrel $150 \mathrm{ppm}$ & 19 & 34 & 55 & 6 & 3 \\
\hline $\mathrm{T}_{8}: \mathrm{T}_{1}+\mathrm{T}_{5}$ & 34 & 52 & 39 & 6 & 1 \\
\hline $\mathrm{T}_{9}: \mathrm{T}_{2}+\mathrm{T}_{6}$ & 28 & 58 & 27 & 6 & 7 \\
\hline $\mathrm{T}_{10}: \mathrm{T}_{3}+\mathrm{T}_{6}$ & 16 & 41 & 18 & 18 & 18 \\
\hline $\mathrm{T}_{11}: \mathrm{T}_{4}+\mathrm{T}_{6}$ & 26 & 48 & 8 & 21 & 8 \\
\hline $\mathrm{T}_{12}: \mathrm{T}_{1}+\mathrm{T}_{7}$ & 27 & 42 & 32 & 9 & 13 \\
\hline $\mathrm{T}_{13}: \mathrm{T}_{2}+\mathrm{T}_{7}$ & 41 & 62 & 24 & 6 & 6 \\
\hline $\mathrm{T}_{14}: \mathrm{T}_{3}+\mathrm{T}_{7}$ & 36 & 60 & 8 & 14 & 15 \\
\hline $\mathrm{T}_{15}: \mathrm{T}_{4}+\mathrm{T}_{7}$ & 18 & 51 & 6 & 28 & 14 \\
\hline $\mathrm{T}_{16}$ : Control & 13 & 26 & 69 & 1 & 3 \\
\hline $\mathrm{SEm}+$ & 1.78 & 0.88 & 2.04 & 0.74 & 0.57 \\
\hline $\mathrm{CD}(\mathrm{p}=0.01)$ & 4.87 & 2.40 & 5.59 & 2.02 & 1.56 \\
\hline $\mathrm{CV} \%$ & 2.91 & 2.29 & 3.58 & 4.14 & 7.54 \\
\hline
\end{tabular}



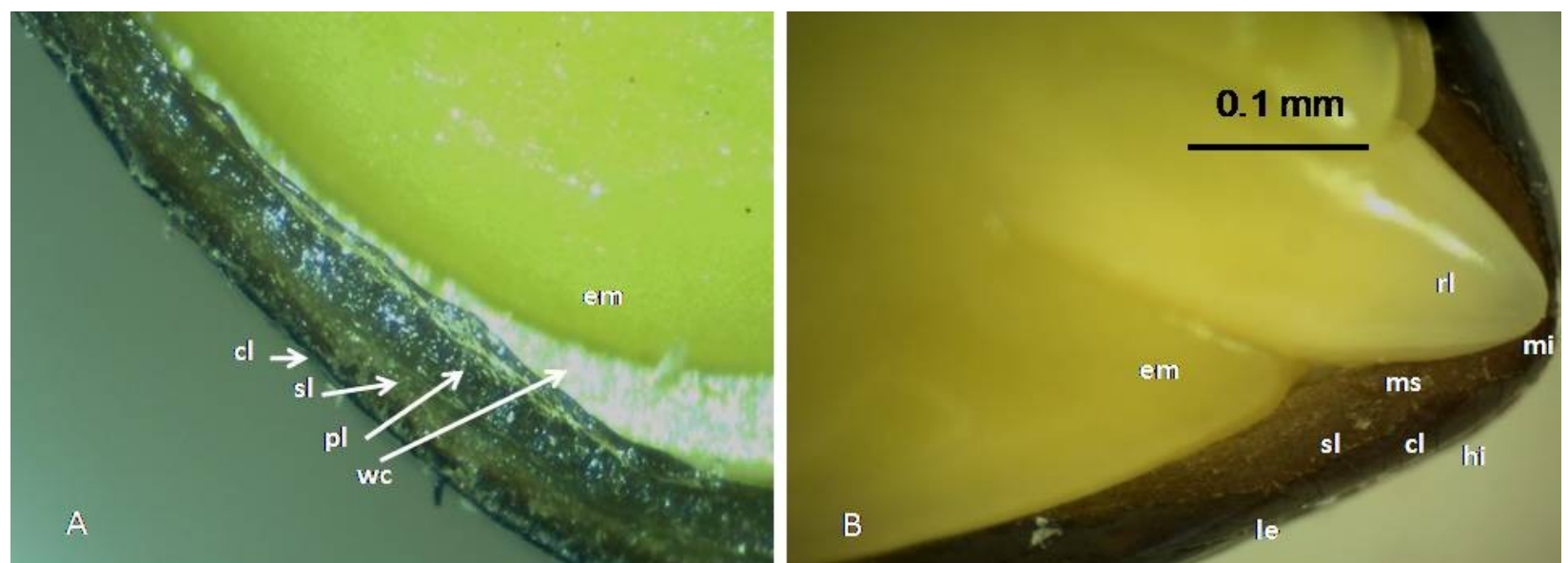

Fig. 2. Longitudinal section of seed coat of C. absus observed by stereo microscopy in extra hilar region (A) and hilar region (B) : ct, cuticle; sl, subcuticular; lp, plaisade layer; wc, white cells; le, lens; hi, hilum; mi. micrpyle; ms, macrosclerids; em, embryo; rl, radical.
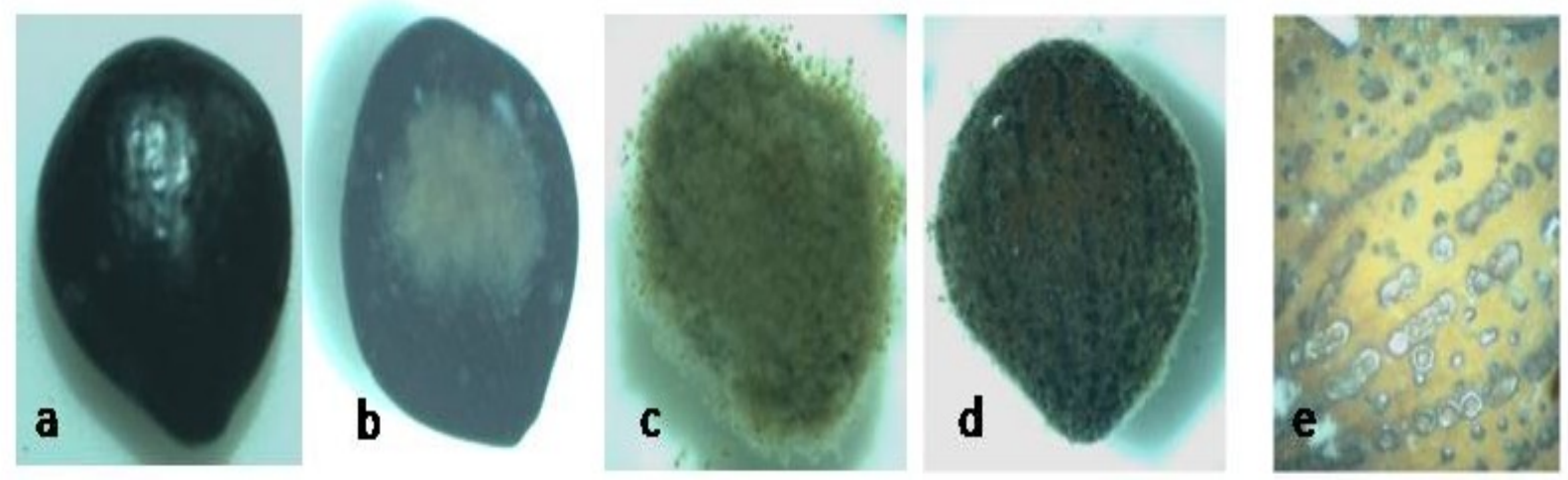

Fig. 3. Morphological changes in the see coat after boiling (a-e). a) Dormant seed with shiny seed coat. b) Formation of cotton like structure on the seed coat (1 min after boiling. c) Seed is covered with mucilaginous material ( 2 mins after boiling). $d$-e) outer cuticular layer is eroded exposing inner sub-cuticular (3 mins after boiling).

mones over water boiling alone. While, seeds treated Ethrel after water boiling $(51 \%)$ did not improved germination significantly when compared to water boiling alone ( $82 \%$ ) and recorded maximum percentage of fresh ungerminated seeds $(28 \%)$.

\section{DISCUSSION}

C. absus seeds have acquired dormancy for adaptation and survival in unfavourable environmental conditions. Hence, structural analysis was made to study the reasons for seed dormancy and techniques to overcome this dormancy.

Structural analysis of seed: Anatomical analysis of C. absus seeds confirmed the features found in Caesalpinoideae. The hilum is between the micropyle and lens (Gunn, 1999) and hilar region is apical. Also the palisade layer was composed of elongated macrosclerides that are tightly packed to resist permeability (Baskin, 2003) to water. Hot water treatment stimulated the hilum region, resulting in the opening of fragile regions at the lens and hilum, allowing water to enter the seeds. Rangaswamy and Nandakumar (1985) reported entry of water thorough hilum and micropyle in Rhynchosia minima (L.). Similar seed behaviour of water entering the seed through lens and hilum was reported in Senna macranthers, (Alexandre et al., 2012).

Seed treatment to overcome dormancy: Freshly harvested seeds of $C$. absus recorded dormancy and poor germination. C. absus belongs to Caesalpiniodeae and physical dormancy has been reported for other species in this family (Villers, 1972; Morrison et al., 1998; Alexandre et al., 2012). Also reported the presence of lignin in the testa of Caesalpiniodeae leading to impermeability for water (Souza and Marcos Filho, 2001). Pre-sowing seed treatments were found to be effective to overcome physical dormancy and improve germination in C. absus. In the present study among the different treatments seeds boiling in water for 5 minutes have recorded maximum percentage of germination.

While, seed treated with plant hormones GA3 and ethrel did not enhance germination significantly over control. Hot water treatment was successful in softening the hard seed coat and made permeable for water entry. Increase in temperature of water has resulted in quick breakdown of leginin content in outer seed coat 


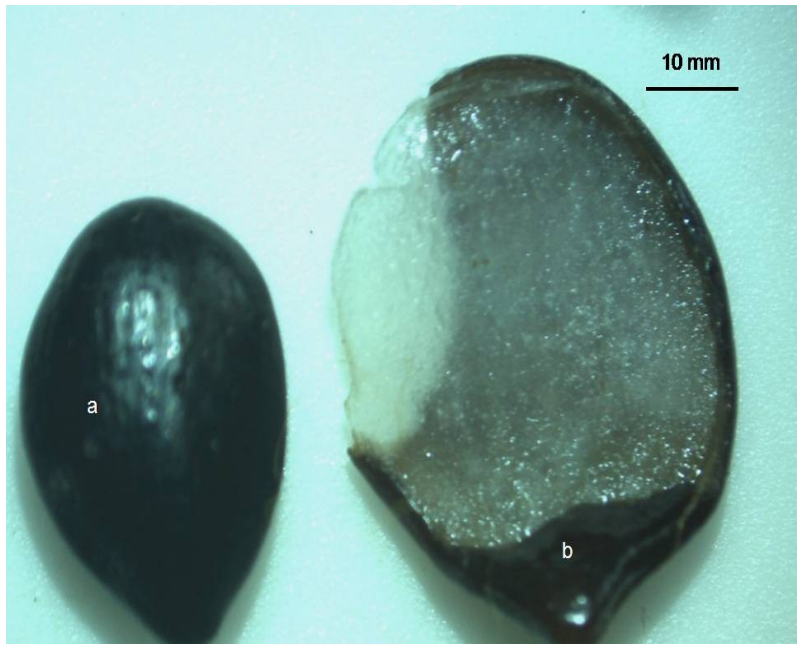

Fig. 4. Morphological changes in seed size after boiling in water a) dormant whole seed b) seed coat of non dormant seed.

and allowed water to entry through hilar region. Agboola and Adedire (1998) demonstrated that sudden dip of dry seeds in boiling water lead to the rapture of the coat wall allowing water to permeate the seed tissues causing physiological changes and subsequent germination of the embryo in hard seed coat species. Duguma et al. (1988) reported high percentage germination in seeds of Leucaenia leucocephala and Acacia nilotica and Amira and Mohamed (2013) reported in Casia fistula after hot water treatment. While, germination decreases when duration of water boiling was increased more than five mins in C. absus. This was due to the damage caused by high temperature for longer period on growing tip of embryo. Although, high temperature can break hard seed coat, they also affect seed viability either through accelerated ageing (Daws et al., 2007) or by the impact of high temperature on cellular processes (Probert, 2000). Germination was faster in water boiled seeds for 5 mins than other treatments. This entail that seed treatment has also resulted in early germination particularly in hot water treatments compared to untreated control.

Similar results were also found in M. meneghiniamam seeds which showed early germination after hot water treatment (Ferat and Ibrahim, 2004). An inverse relation was observed for percentage germination and percentage hard seeds in all seed treatments. When germination is at high peak percentage hard seed was at the lowest peak. This clearly says that presence of hard seeds due to physical dormancy leads to poor germination in freshly harvested seeds (Gaddanakeri et al. (2009).

\section{Conclusion}

In conclusion $C$. absus self seeding has low germination because of hard seed coat which can be removed after seed treatment. Results in the present study showed that seed coat has four layers of cells which are impermeable to water. While, hot water treatments helped in removing outer seed coat and exposing inner layers for water permeability in hilar region. Seeds boiled in water for 5 mins effectively removed physical barrier for imbibition and showed maximum germination compared to all other treatments. This confirmed that $C$. absus seeds has hard seed coat made up of four layers of different kinds of cells which can break with hot water. Further, plant hormone has no effect on these hard coat layers of seeds.

\section{REFERENCES}

Agboola, D.A. and Adedire, M.O. (1998). Response of treated dormant seeds of three species to germination promoters. Nigerian Journal of Botany, 11: 103 - 109

Alexandre Souza de Paula, Carolina Maria Luzia Delgado, Maria Terezinha Silveira Paulilo, Marisa Santos (2012). Breaking physical dormancy of Cassia leptophylla and Senna macranthera (Fabaceae: Caesalpinideae) seeds: water absorption and alternating temperatures. Seed Science Research, 1-9 http://journals.cambridge.org abstract_S096025851200013X

Ameer Junaithal Begum M., Vijayakumar A. and Selvaraju, P. (2013). Standardization of seed dormancy breaking treatment in Senna (Cassia auriculata). Journal of plant breeding and Crop science, 5(11): 220-223

Amira, S.S. and Mohamed, S.A. (2013). Effects of Sulfuric Acid and Hot Water Pre-Treatments on Seed Germination and Seedlings Growth of Cassia fistula L. American-Eurasian. Journal of Agriculture Environmental Science, 13 (1): 07-15

Baskin, C.C. (2003). Breaking of physical dormancy in seed focusing on the lens. New Phytologist, 158: 227-238.

Baskin, C.C. and Baskin, J.M. (2001). Seeds: Ecology, biogeography and evolution of dormancy and germination. Academic Press, London.

Bewley, J.D. and Black, M. (1994). Seeds: Physiology of development and germination ( $2^{\text {nd }}$ edition). Plenum Press, New York.

Duguma, B., Kang, B.T. and Okali, D.U. (1988). Factors affecting germination of Leucaena leuocephala. Seed Science \& Technology, 16: 489-500.

Daws, M.I., Kabadajic, A., Manger, K. and Kranner, I. (2007). Extreme thermo-tolerance in seeds of desert succulents is related to maximum annual temperature. South African Journal of Botany, 73:262-265.

Ferat Uzum and Ibrahim Aydin (2004). Improving germination rate of medicago and trifolium species. Asian Journal of Plant Sciences, 3(6): 714-717.

Finch-Savage, W.E. and Leubner- Metzger, G. (2006). Seed dormancy and the control of germination. New Phytologist, 171: 501-523.

Gaddanakeri, S.A., Hosmath, J.A. and Hunshal, C.S. (2009). Investigations on unexploited medicinal legume, Cassia absus Linn. International Journal of Agricultural Sciences, 5(2): 516-517

Gunn, C.R. (1999). Fruits and seeds of genera in subfamily Caesalpinioideae (Fabaceae). United States Department of Agriculture Technical Bulletin, 1755: 1-408.

Li Xiaojie, Jerry M. Baskin and Carol C. Baskin (1999). Anatomy of two mechanisms of breaking physical dormancy by experimental treatments in seeds of two north american rhus species (Anacardiaceae). American Journal of Botany 86 (11): 1505-1511 
Ma, F., Cholewa, E., Mohamed, T., Peterson, C.A. and JZEN, M.G. (2004). Cracks in the palisade cuticle of soybean seed coats correlate with their permeability to water. Annals of Botany, 94: 213-228.

Morrison, D.A., Mcclay, K., Porter, C. and Rish, S. (1998). The role of the lens in controlling heat-induced breakdown of testa-imposed dormancy in native Australian legumes. Annals of Botany, 82 (5): 40-44

Negi R.S. and Sharma, K.C. (2012). Seed germination in a medicinally important plant- Cassia auriculalta. Cibtech Journal of Pharmaceutical Sciences, 1 (1): 12-13

Panse, V.G. and Sukhatme, P.V. (1967). Statistical methods for agricultural workers ( ${ }^{\text {nd }}$ Edn). ICAR New Delhi. Pp 381

Probert, R.J. (2000). The role of temperature in the regulation of seed dormancy and germination. In: Fenner M. Ed. Seeds: The Ecology of Regeneration in Plant Communities, 2nd edition, CABI Publishing, Wallingford. pp 261-292,

Rangaswamy, N.S. and Lakshmi Nandakumar (1985). Correlative Studies on Seed Coat Structure, Chemical Composition, and Impermeability in the Legume Rhynchosia minima. Botanical Gazette, 146 (4): 501-509

Souza, F.H.D. and Marcos Filho, J. (2001). The seed coat as a modulator of seed-environment relationships in Fabaceae. Revista Brasileira de Botanica, 24: 365-375.

Souza Thaysi Ventura de,, Caroline Heinig Voltolini,, Marisa Santos and Maria Terezinha Silveira Paulilo (2012). Water absorption and dormancy-breaking requirements of physically dormant seeds of Schizolobium parahyba (Fabaceae - Caesalpinioideae). Seed Science Research, 1-8

Villers, T.A. (1972). Seed dormancy. pp. 220-282 in Kozlowsky, T.T. (Ed.) Seed biology. New York, Academic Press. 